\title{
The measurement and validation of the nonsteady-state rates of C-peptide appearance in the dog
}

\author{
T. Morishima ${ }^{1,2}$ S. Pye ${ }^{1,2}$, K. Polonsky ${ }^{3}$, and J. Radziuk ${ }^{1,2}$ \\ ${ }^{1}$ Department of Medicine, McGill University, Montreal, and ${ }^{2}$ Departments of Medicine and Physiology University of Western Ontario London, \\ Ontario, Canada; ${ }^{3}$ Department of Medicine, University of Chicago, Pritzker School of Medicine, Chicago, Illinois, USA
}

Summary. In order to verify the calculation of nonsteady rates of secretion of C-peptide, dog C-peptide was infused into 5 normal conscious dogs at varying rates. Using the decay curve obtained following a preliminary injection of C-peptide in each animal, concentrations during the infusion, and mathematical deconvolution, the rate of appearance of the C-peptide was calculated. This rate was within $12 \%$ of the infusion rates, with $94 \%$ of the C-peptide infused recovered in the cal- culation. The metabolic clearance of C-peptide was calculated to be $10.1 \pm 1.0 \mathrm{ml} / \mathrm{min}$ following both its injection and constant infusion. In conclusion, within the limits of the errors determined, C-peptide and therefore insulin secretion can be calculated on a continuous basis under nonsteady-state conditions.

Key words: C-peptide, insulin secretion kinetics.
The measurement of insulin secretion in response to various perturbations in the metabolic state is evidently of great importance. The determination of this rate based on peripheral insulin concentrations alone has been precluded because of the large first-pass hepatic uptake of newly-secreted insulin [1-5]. This has moreover been shown to vary secondary to the levels of insulin, the route of nutrient administration and disease state [6-13], using measurements of global insulin clearance [5-8] or portal/arterial hepatic venous differences across the liver in the dog [9-14] and arterial/hepatic vein differences in man [12]. C-peptide has been shown to be secreted from the $\mathrm{B}$ cell on an equimolar basis with insulin [15]. In contrast to insulin, it almost completely escapes the splanchnic bed in rats [16] or may undergo a low constant extraction in pigs [17]. Recent evidence in the $\operatorname{dog}[18]$ indicates that hepatic extraction is negligible.

With this in mind, plasma and urinary concentrations of C-peptide have been used as indicators of insulin secretion [19-21]. In particular, continuous determinations of insulin secretion have been made in man during metabolic perturbations by measuring C-peptide appearance using arterial-hepatic venous differences of the C-peptide [22].

Alternatively, the linearity of C-peptide behaviour suggested by Faber er al. [23] was used to calculate its rate of appearance based on a two compartment model [24]. In the following work we have exploited the linearity of the C-peptide system to demonstrate that a model-independent approach to the calculation of
C-peptide rates of appearance is feasible and to determine the degree of accuracy with which these calculations can be performed. The validation of the calculations necessarily reaffirms the linearity of C-peptide kinetics. In the extrapolation of the peripheral rate of $\mathrm{C}$ peptide appearance to that of insulin secretion, the remaining assumptions are (1) that the hepatic extraction of C-peptide is minimal and (2) that insulin and C-peptide are in fact released from the B cell at equimolar rates.

\section{Materials and methods}

Dog C-peptide was isolated from pancreas removed from normal mongrel dogs [17]. The identity and purity of the isolated dog C-peptide were determined by the amino acid analysis. For the infusion, dog C-peptide was dissolved in $0.9 \% \mathrm{NaCl}$ containing $1 \%$ bovine serum albumin (Schwarz/Mann,) and Trasylol (4000 KIU in $100 \mathrm{ml}$ of infusate, Miles Pharmaceuticals, Toronto, Canada).

\section{Experimental protocol}

Five normal conscious mongrel dogs of a mean weight of $15.2 \pm 0.9 \mathrm{~kg}$ were used after $18 \mathrm{~h}$ fast. Two polyethylene cannulae (Intramedic Polyethylene Tubing, Becton, Dickinson and $\mathrm{Co}$,) were inserted under local anesthesia with lidocaine (Xylocaine 2\%, Astra Pharmaceuticals Ltd,) into a jugular vein for the administration of the C-peptide and into the inferior vena cava via a saphenous vein for blood sampling. After a stabilization period of 45 to $60 \mathrm{~min}$, three basal blood samples were taken at $10 \mathrm{~min}$ intervals (at $-30,-20$, and $-10 \mathrm{~min}$ ). In order to obtain the response curve of plasma C-peptide to a bolus of C-peptide, a known amount of dog C-peptide ( 12.5 to $28 \mathrm{nmol}$ ) was injected within $15 \mathrm{~s}$ at time $=0$ and blood samples were taken at $1,2,3,4,5,7$, $9,11,14,17,20,25$ and $30 \mathrm{~min}$ and thereafter every $10 \mathrm{~min}$ until 
$120 \mathrm{~min}$. At $120 \mathrm{~min}$, the infusion of $\operatorname{dog}$ C-peptide was initiated with a Sage infusion pump (Model 355, Sage Instruments,). During the period of the first $60 \mathrm{~min}$ (from 120 to $180 \mathrm{~min}$ ), the C-peptide was infused at a constant rate and then the infusion rates were varied using predetermined infusion patterns (sinusoidal curve, etc) for the next $2 \mathrm{~h}$. Blood samples were taken at 5 to $15 \mathrm{~min}$ intervals during the first constant infusion period and every 5 min during the next variable infusion period. In experiments 3 and 5, blood sampling was done every $2 \mathrm{~min}$ during the first $30 \mathrm{~min}$ of the varible infusion period, since the infusion rates of $\mathrm{dog} C$-peptide were changed rapidly during this period.

Sample blood $(2 \mathrm{ml})$ was drawn into chilled tubes containing $1000 \mathrm{KIU}$ of Trasylol and $2.4 \mathrm{mg}$ ethylenediaminetetraacetate (EDTA, Fisher Scientific $\mathrm{Co}$,). The plasma was separated promptly and stored at $-20^{\circ} \mathrm{C}$ until assayed.

\section{Analytical procedures}

Plasma concentrations of dog C-peptide were measured by radioimmunoassay using rabbit antiserum against dog C-peptide [17]. Insulin, glucagon, and pancreatic polypeptide did not cross-react with the antibody used at concentrations up to $1000 \mathrm{pmol} / \mathrm{ml}$. Interassay variation was $\pm 6 \%$ and intraassay variation $\pm 5 \%[25]$.

\section{Calculations and statistical analysis}

If the linearity of the C-peptide system is assumed, the response of the system, $\mathrm{C}(\mathrm{t})$ (concentration of plasma $\mathrm{C}$-peptide at time $\mathrm{t}$ ), to an arbitrary input, $R(t)$ (rate of $C$-peptide appearance at time $t$; secretion or infusion), can be obtained from the following convolution integral:

$\mathrm{C}(\mathrm{t})=\mathrm{C}_{0}+\int_{0}^{\mathrm{t}} \mathrm{R}(\tau) \mathrm{h}(\mathrm{t}-\tau) \mathrm{d} \tau$

where $h(t)$ is the response of plasma C-peptide concentrations to a unit bolus of $\mathrm{C}$-peptide and $\mathrm{C}_{0}$ is the concentration of $\mathrm{C}$-peptide at time zero.

The most stringent test for the linearity of the dog C-peptide system, therefore, would be a direct test of this formula [Eq (1)]. The response to a unit injection of $\mathrm{C}$-peptide is $\mathrm{h}(\mathrm{t})$. In our studies this corresponds to a series of data points describing a decay curve. In order to facilitate the solution of equation (1), this decay curve was fitted by a series of exponentials. The initial values for the parameters were generated using a peeling procedure with the final fit being determined by nonlinear least squares methodology [26]. Two or three exponentials were fitted to the data. Since no model structure is being hypothesized, the only consideration is a good fit to the data from the earliest samples until these fall below the detectable limit. The goodness of fit was assessed using the sample multiple coefficient of variation (e.g. 27). Since the system was presumed linear, the basal concentrations of C-peptide were subtracted from the concentrations determined after injection. The unit impulse response function, $h(t)$ was then determined by dividing the fitted curve by the amount of C-peptide injected. This quantity was determined by radioimmunoassay of an appropriately diluted infusate.

We now have an estimate of $h(t)$ in functional form and $C(t)$ as a series of data points during an experiment. This problem does not generally lead to a stable solution without the introduction of smoothing [28]. The approach taken in reference [29] is therefore to define $R(t)$ as a series of polynomials of variable degrees with appropriate continuity and smoothness conditions at the joining points (a method somewhat more general than spline-fitting). The coefficients of all the polynomials are then simultaneously obtained using least-squares procedures and the data points, $\mathrm{C}\left(\mathrm{t}_{i}\right) \mathrm{i}=1, \mathrm{n}$ and the function $\mathrm{h}(\mathrm{t})$. As before, the basal concentration $\mathrm{C}_{0}$ (equation [1]) is subtracted from the data points.

The curves calculated in this way can then be compared to the infusion rates of $\mathrm{C}$-peptide. This was done both by determining the areas under the infusion curve and the calculated rate of appearance and the limits of confidence on the slope determined.

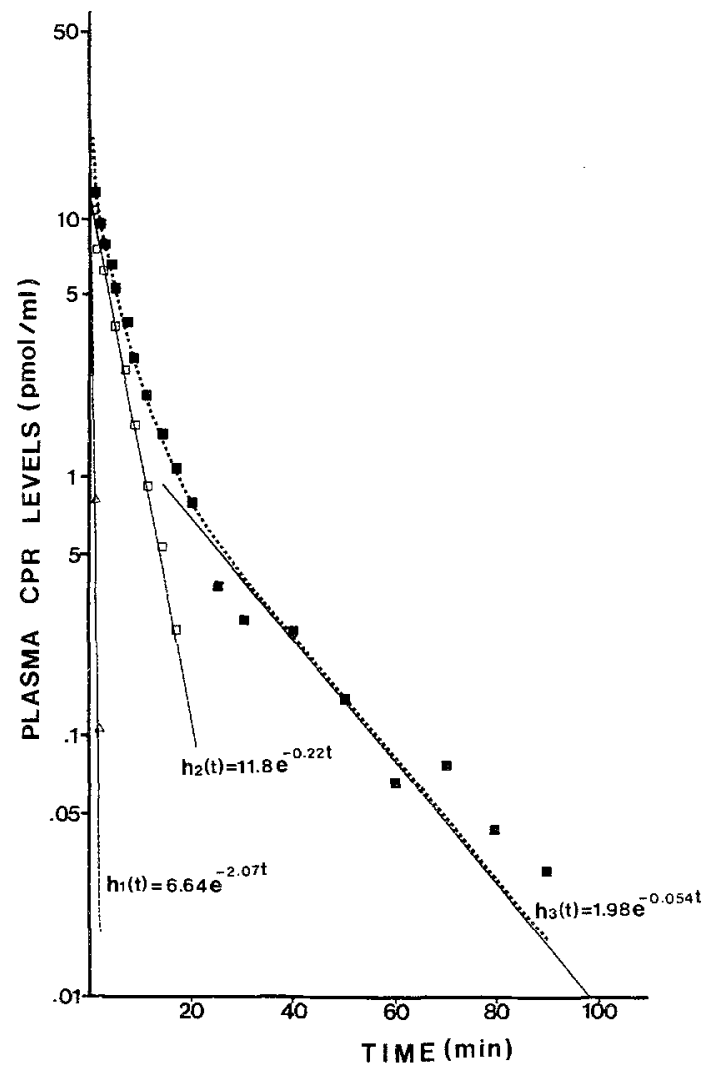

Fig. 1. A decay curve of plasma C-peptide levels from a single study which follows the injection of a bolus of dog C-peptide. Baseline (preinjection) values have been subtracted from the C-peptide concentrations shown. The h(t) shown here is subsequently divided by the dose injected for use in equation [1]. [...h $\mathrm{h}(\mathrm{t})=\mathrm{h}_{1}(\mathrm{t})+\mathrm{h}_{2}(\mathrm{t})+\mathrm{h}_{3}(\mathrm{t}) ; \mathbf{a}$ : plasma CPR levels; $\left.\square: \mathbf{\square}-\mathrm{h}_{3}(\mathrm{t}) ; \Delta: \square-\mathrm{h}_{2}(\mathrm{t})\right]$

\section{Results}

Figure 1 represents a typical decay curve following the injection of a bolus of dog C-peptide. The exponentials are resolved into their component parts. It can be seen that the two principal components have $t_{1 / 2} s$ of 10 and 25 min. It should be noted that an impulse response function was determined for each animal individually. It was then used in equation (1) to calculate the rates of appearance of C-peptide, $R(t)$, from its plasma concentrations during the infusion of the peptide at variable rates. Figures 2-4 show plasma C-peptide concentrations in three animals and the calculated rates of appearance compared to the actual infusion rates. Figures 5 and 6 display the comparison for two further studies. It can be seen that equilibration occurs very quickly in the dog as evidenced by the rapid decay curve (Fig. 1). The process of extracting the rate of appearance from the plasma concentrations therefore becomes most important when the rate of appearance is changing the most rapidly. An illustration of this can be seen in Figure 2, where the plasma concentrations are shifted and not as well resolved as the curve obtained by deconvolution. Table 1 summarizes the amount of Cpeptide infused as well as the ratio of the areas under 

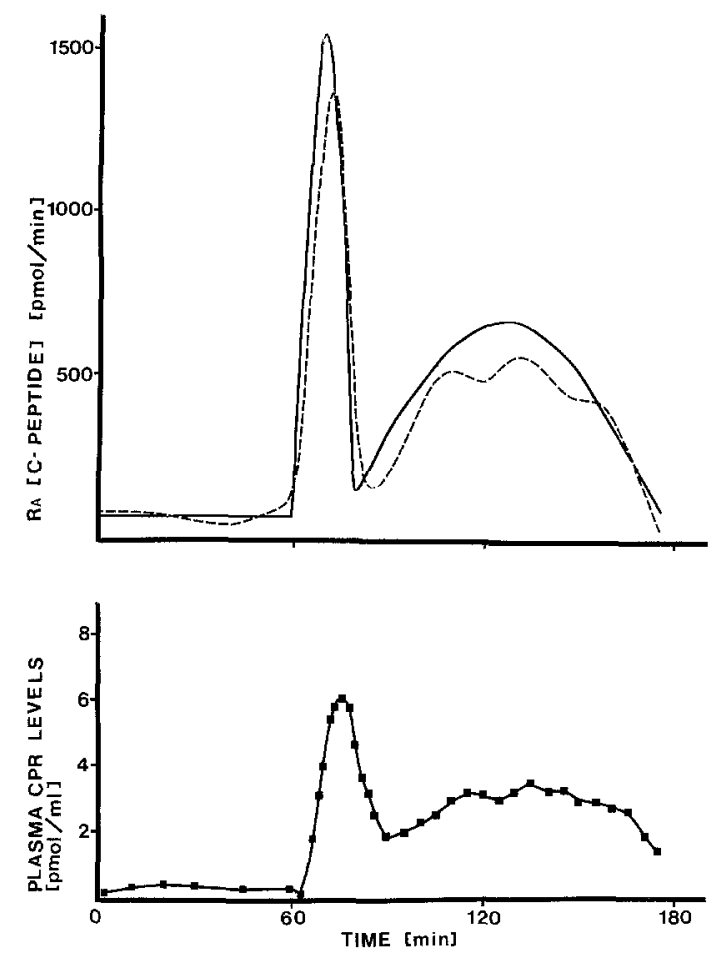

Fig. 2. C-peptide concentrations with the actual (solid line) and calculated (dotted line) infusion rates in Study 1
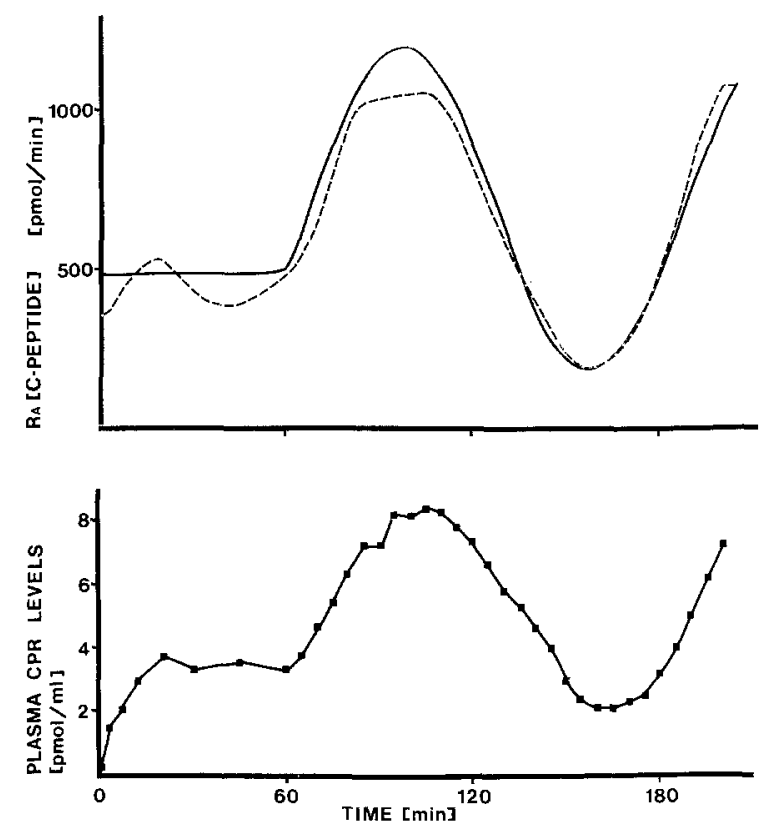

Fig.3. C-peptide concentrations with the actual (solid line) and calculated (dotted line) infusion rates in Study 2.

the calculated and infused curves. It can be seen that in the mean, $94 \%$ of the infused C-peptide can be accounted for. As a more strigent assessment of deviations between the calculated curves and the actual infusion rates, the sum of the absolute value of the areas between the two curves is taken as an estimate of the error. From Table 2, it can be seen that this error amounted to $12 \%$ of the infused C-peptide. A regression line (Fig.7) was
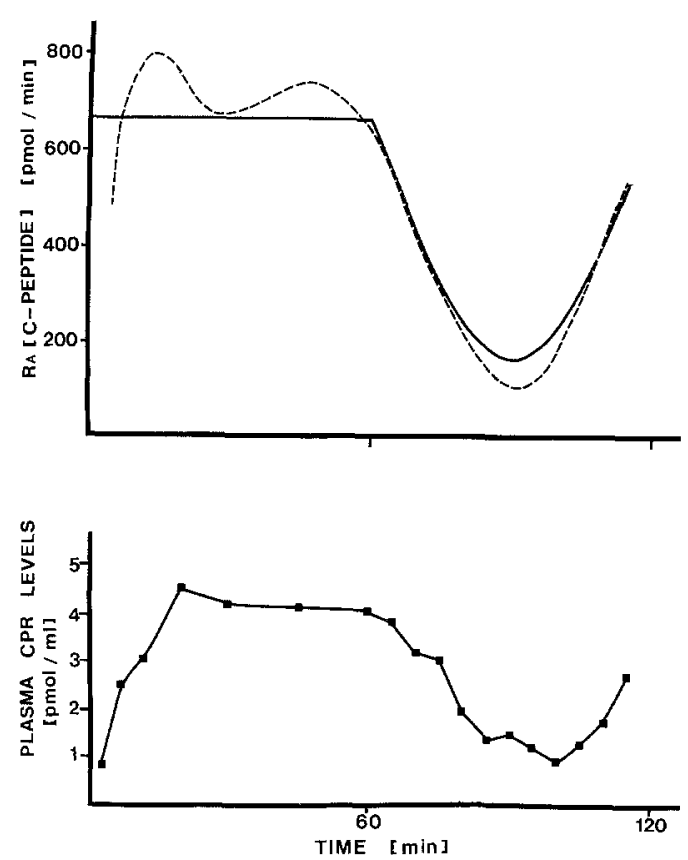

Fig.4. C-peptide concentrations with the actual (solid line) and calculated (dotted line) infusion rates in Study 3

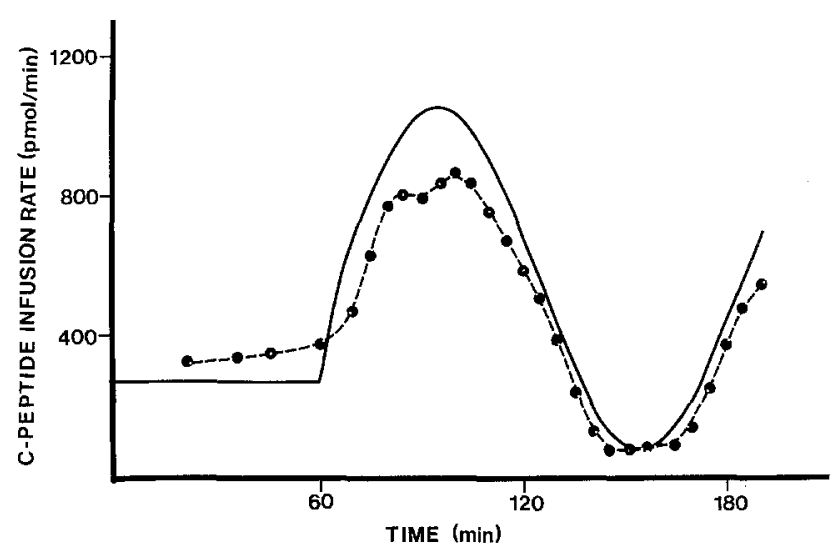

Fig.5. The actual (solid line) and calculated (dotted line) infusion rates in Study 4

also drawn relating calculated rates of C-peptide appearance at intervals throughout the five studies and the corresponding rates of infusion. The intercept is 10.2 and is not significantly different from zero $(p>0.5)$. The slope is 0.950 with $95 \%$ confidence limits of \pm 0.032 . It is evident that the hypothesis that the slope must be one is rejected and reaffirms the small bias which is seen by summing the absolute areas. With these errors taken in- 
to consideration, as shown in Figures 2-6, the rate of Cpeptide appearance can, however, be reasonably determined in vivo.

Table 2 shows the coefficients in the exponential fits to the decay curves following injection. These are seen to vary over a two- to three-fold range. That the two or three exponential fit is completely adequate is indicated by the very high values of $\mathrm{R}^{2}$, the sample multiple coefficient of determination. The metabolic clearance rate is calculated from both the injection data and from the plasma concentrations during constant infusion. It varies from 8 to $13 \mathrm{ml} \cdot \mathrm{kg}^{-1} \cdot \mathrm{min}^{-1}$ with a mean of $10.1 \pm 0.9 \mathrm{ml} \cdot \mathrm{kg}^{-1} \cdot \mathrm{min}^{-1}$. The secretion rate at basal C-peptide concentrations (mean: $0.14 \pm 0.01 \mathrm{pmol} / \mathrm{ml}$ ) was estimated by multiplying the MCR by these concentrations and was found to be $1.40 \pm 0.14 \mathrm{pmol}$. $\mathrm{kg}^{-1} \cdot \min ^{-1}$.

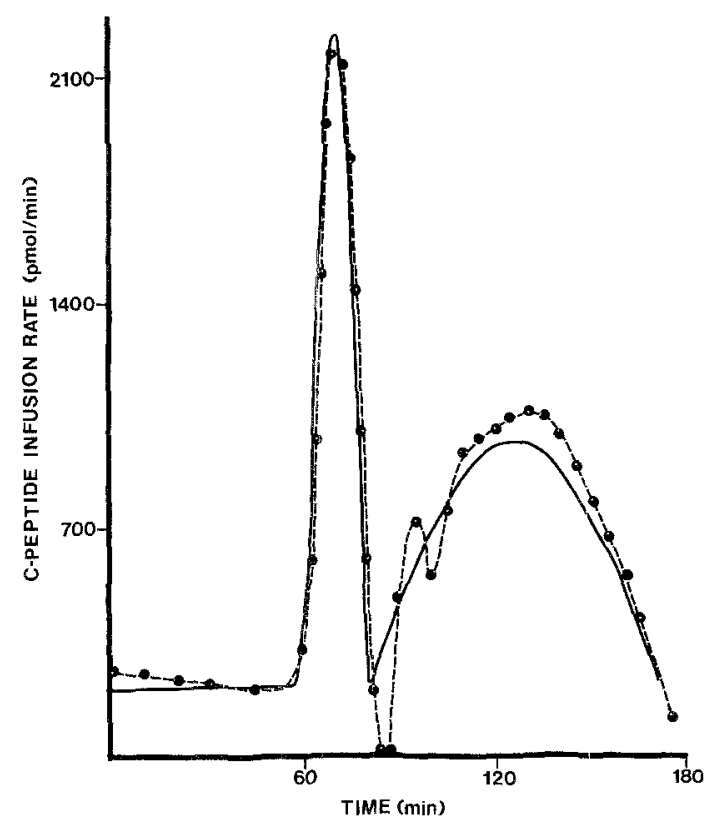

Fig. 6. The actual (solid line) and calculated (dotted line) infusion rates in Study 5

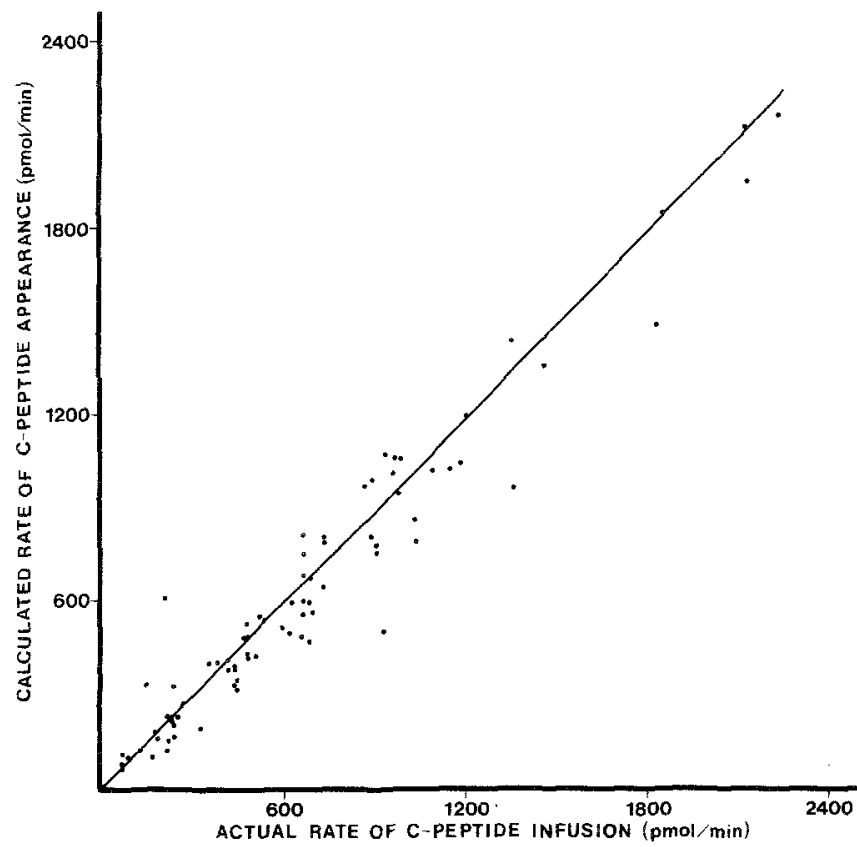

Fig. 7. Regression calculation between calculated rates of C-peptide appearance and actual infusion rate. The line shown is that for equality

Table 1. Comparison between the actual and calculated rates of infusion of C-peptide during variable C-peptide infusion

\begin{tabular}{lllll}
\hline $\begin{array}{l}\text { Exp } \begin{array}{l}\text { Weight } \\
(\mathrm{kg})\end{array} \\
\end{array}$ & $\begin{array}{l}\text { Total C-peptide } \\
\text { infused } \\
\text { (nmol) }\end{array}$ & \begin{tabular}{l}
$\mathrm{AUC}^{\mathrm{a}}$ (calculated) \\
\cline { 3 - 4 }
\end{tabular} & $\begin{array}{l}\mathrm{AUC} \text { (actual) } \\
(\%)\end{array}$ & $\begin{array}{l}\mathrm{A} \mathrm{AUC}^{\mathrm{b}} \text { (actual) } \\
(\%)\end{array}$ \\
\hline 1 & 15.4 & 55.2 & 101.1 & 9.7 \\
2 & 15.2 & 132.8 & 94.1 & 6.9 \\
3 & 17.3 & 68.7 & 86.7 & 13.9 \\
4 & 18.9 & 98.5 & 101.3 & 12.2 \\
5 & 16.1 & 86.5 & 86.5 & 18.1 \\
\hline
\end{tabular}

${ }^{a}$ Area under the curve of calculated appearance rate; ${ }^{b}$ Area under the curve of actual infusion rate; $\Delta$ The absolute values of the area between actual infusion rate and calculated appearance rate

Table 2. Decay coefficients and metabolic clearance rates of C-peptide

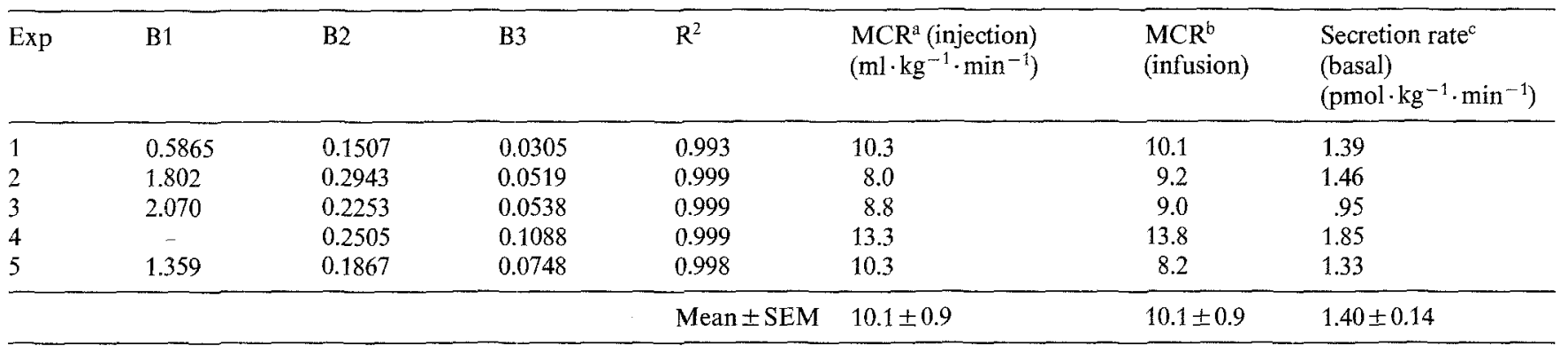

$B 1, B 2, B 3-$ from exponential fit of response to injection: $A 1 \exp (-B 1 t)+A 2 \exp (-B 2 t)+A 3 \exp (-B 3 t)$.

$\mathrm{R}^{2}$ is the sample multiple coefficient of determination.

${ }^{a}$ MCR determined from: amount injected $\div(\mathrm{A} 1 / \mathrm{B} 1+\mathrm{A} 2 / \mathrm{B} 2+\mathrm{A} 3 / \mathrm{B} 3) ;{ }^{b} \mathrm{MCR}$ determined from: steady-state rate of infusion $\div \mathrm{S} . \mathrm{S}$. plasma concentration of C-peptide; ${ }^{\mathrm{c}}$ Secretion rate under basal conditions from: MCR X basal concentration of C-peptide 


\section{Discussion}

In order to ascertain whether the peripheral rate of appearance of C-peptide could be assumed to be equivalent to the rate of insulin secretion under general nonsteady-state circumstances in vivo, it must be considered whether: (1) insulin and C-peptide are secreted from the pancreas at equimolar rates; (2) there is an effect of the liver on C-peptide dynamics, degradative or otherwise; (3) the behaviour of C-peptide in the systemic circulation is such that its rate of appearance can be predicted from its plasma concentrations.

That insulin and C-peptide are secreted at equal rates by the $\mathrm{B}$ cell has been initially suggested by $\mathrm{Ru}$ benstein et al. [15]. This has more recently been reiterated in both man [30] and the dog [18], where it has been shown that the portal molar ratio of C-peptide to insulin is close to one.

Additional evidence can be sought in the comparison of the basal rate of insulin secretion which can be determined from our data and those previously measured using the arterial-portal venous gradient of insulin together with an estimate of the hepatic blood flow [31-33]. Alternatively, insulin was infused intraportally into pancreatectomized dogs to obtain normal basal insulin concentrations [34]. All these approaches yielded estimates of between 0.2 and $0.3 \mathrm{mU} \cdot \mathrm{kg}^{-1} \cdot \mathrm{min}^{-1}$. Our results gave a rate of $1.40 \pm 0.14 \mathrm{pmol} \cdot \mathrm{kg}^{-1} \cdot \mathrm{min}^{-1}$, equivalent to $0.2 \mathrm{mU} \cdot \mathrm{kg}^{-1} \cdot \mathrm{min}^{-1}$ which compares exactly with the majority of the above estimates.

Since C-peptide kinetics are considered in the systemic circulation, the effects of the liver on newly-secreted C-peptide on first passage must also be considered. These effects are two-fold. Firstly, the liver may extract a certain fraction of C-peptide. It has, however, been shown that C-peptide almost completely escapes the splanchnic bed in rats [16] and dogs [18], or may undergo a low constant $12 \%$ extraction in pigs [17]. In addition, at least porcine C-peptide has been found to escape the human liver entirely [35]. Secondly, the transit times along the pathways followed through the liver by molecules which distribute through the extracellular space are not all equal. This will lead to a spreading of the hepatic venous appearance of the bolus of such a substance injected into the portal vein. This spreading has been well characterized using indicator dilution techniques, and it has been found that the mean transit time through the liver is short and the (extrapolated) maximal transit time is near $30 \mathrm{~s}$ [36]. This could be corrected using deconvolution - as is routinely done, for example, in the extraction of indicator dilution curves themselves from data contaminated by catheter distortion [37]. The corrections arising from this would be lower than the other errors which arise in this type of study because the time-scale of their occurrence is much shorter than that of the events being observed. They are therefore, in general, neglected.

The final consideration, and the one addressed in these studies, are the systemic kinetics of C-peptide. If the peptide behaved in a linear manner, then all the parameters describing this behaviour would be constant. In particular, the fractional rate of removal would be constant. Under steady-state conditions, this means that the C-peptide rate of appearance would equal its plasma concentration times the metabolic clearance rate (MCR). Once the MCR had been determined it could be applied to any steady-state plasma level in the same experiment. Under nonsteady-state conditions this does not, in general, hold true. If the changes are very slow compared to the dynamic response of the system, then some approximation of the rate of appearance could be obtained by this calculation out of steady-state. This would be the case if one considers an infusion rate which increases by the same increment every five minutes. Using the impulse response function from experiment 2 (Table 2) it can be calculated that at 5 min the rate of infusion estimated from the product of the MCR and the concentration would be $60 \%$ of the actual rate, then $68 \%, 73 \%$ and $77 \%$ at 10,15 and $20 \mathrm{~min}$ respectively. It can be seen that the error will never decrease to zero, yielding a true bias in the calculation. On the other hand, an overestimate would be consistently obtained if the rate of infusion were decreasing. Results similar to this appear to have been obtained [25] when the calculation was performed in this way.

If the system is linear, stationary and not in steadystate, an appropriate description of its kinetics must therefore be used. The most general expression of these kinetics is equation (1). Here $h(t)$ is the impulse response function or the curve of plasma concentrations following a unit injection of C-peptide. It is obvious that the mathematical description of $\mathrm{h}(\mathrm{t})$ is not important as long as appropriate interpolations can be made and the curve can be extrapolated to the length of the experiment. Because of the shape of the curve, a sum of exponentials was fitted to the data. The number of these is not important as long as the extrapolations made are valid or the value of $h(t)$ is insignificant beyond the point at which it is experimentally determined. It can be seen (e.g. Fig. 1) that the latter case is certainly true. In addition, the fits to the data are excellent (Table 2).

It is also evident that if one has a one, two or three exponential decay, the minimum number of compartments necessary to model the system would be one, two or three respectively. At the same time, beyond the single-compartment case, the modelling would no longer be unique without additional assumptions. Therefore, unless additional structural information is required modelling is not necessary. From the point of view of obtaining the rate of C-peptide appearance, all these methods (deconvolution, compartmental modelling [241) are equivalent. What we have attempted to do here, therefore, is to show that the most general approach is feasible and to define the limits of its validity.

The overall error in these calculations has been found to be approximately $12 \%$. In addition, there ap- 
pears to be a slight bias so that the calculated values are a few percent below the actual infusion rates (Fig. 7). The sources of these errors will now be discussed.

It was stated previously that the intraassay variation in the C-peptide radioimmunoassay was $\pm 5 \%$. Again, because of the linearity of the system, this will automatically yield an error of $\pm 5 \%$ in the calculated $R_{a}(t)$ from Eq. (1). This estimate presupposes that $h(t)$ is completely accurate. In fact, it is also based on data increasing the error maximally to $\pm 10 \%$. The errors in these studies may be somewhat higher since the C-peptide concentrations were frequently high. Many-fold dilutions will yield somewhat lower values which could easily cause the small bias observed. The high C-peptide concentrations attained, on the other hand, have two advantages. If the system is shown to be linear even under conditions where saturation of removal mechanisms may be expected to occur, then it certainly will be linear at lower concentrations. In addition, if elevated C-peptide levels affect the basal endogenous secretion so that $C_{0}$ in equation (1) cannot be assumed constant, then the error incurred by subtracting a constant $C_{0}$ will be minimal at high C-peptide levels. It should, however, be possible to eliminate this problem by the infusion of somatostatin during exogenous C-peptide administration to suppress its endogenous secretion using a protocol similar to that of Rudenski et al. [38]. An additional source of errors when the slope changes very rapidly arises from the fact that a set of connected polynomials is fitted to the rates of appearance in equation (1). This may lead to oscillations as can be seen, for example, in Figure 6. If this is kept in mind it can be seen that an error of $\pm 5 \%$ to $10 \%$ (or $10-12 \%$ in absolute areas) are most likely realistic limits for these estimates.

It is most obvious in Figure 2 that there is both a phase shift and a loss of resolution in the plasma concentration (relative to the infusion rates), and that this is effectively regained upon deconvolution. Methodology for the extraction of the rate of appearance of C-peptide using parameters which describe its kinetics, therefore, becomes increasingly important as the time course of the changes approaches the time constant of the injection response. In man, this occurs at substantially slower rates of change since the decay of C-peptide concentrations is slower than in the dog [23]. This is reflected in a metabolic clearance rate of $4.4 \mathrm{ml} / \mathrm{kg}$-min compared with $10.1 \mathrm{ml} / \mathrm{kg}$-min obtained here in dogs [23, 39]. Since the applicability of a deconvolution or analgous analysis of the data is entirely equivalent to the assertion of the linearity of a system, the only requirement for the complete assurance of the validity of the calculation of C-peptide appearance in man is a demonstration of the linearity of its kinetics. This has been provided by Faber et al. [23]. Therefore the results shown here are directly applicable to the calculation of C-peptide kinetics in man. The two-compartment method of Eaton et al. [24] is therefore valid with the proviso that under ideal conditions it would be useful to inject C-peptide into each individual where its subsequent secretion is to be measured rather than using an average decay curve [24]. It can be seen that even in dogs there is a rather wide variation in the decay coefficients (Table 2), and because of the slower decay it would be even more important to account for this in man.

It is frequently necessary to compare the rate of insulin secretion in the same subject under two sets of physiological or therapeutic circumstances, e.g. following different meals or different therapeutic regimens. As has been discussed [40], if the injection response $h(t)$ remains the same between two studies, the area under the C-peptide concentration curve is proportional to the area under the secretion curve. This confirms the validity of comparing the C-peptide response following oral and intravenous glucose in this way [41]. It also explains why urinary C-peptide which, in effect, represents a fraction of the integral of the concentration curve often correlates well to an otherwise determined insulin secretion rate (e.g. 42). It is assumed in such calculations that none of the factors which might affect urinary C-peptide excretion (e.g. glomerular filtration rate) should change between two studies which are compared.

In conclusion, we have shown that peripheral C-peptide concentrations can be used to measure its rate of appearance. Given the assumptions discussed, these rates represent the rates of insulin secretion by $B$ cells in a continuous fashion. The error limits of such a calculation are of the order of $10 \%$. All that is required is the preliminary determination of the concentration response to a bolus injection of $\mathrm{C}$-peptide in each individual. Because mathemathical deconvolution yields a valid assessment in dogs, and human C-peptide kinetics have also been shown to be linear, the calculation is also valid in man.

Acknowledgements. The authors would like to thank K. Kranz for her expert technical assistance and Céline Péreira for typing the manuscript. This work was supported by the Canadian Diabetes Association. J. Radziuk was a recipient of a Juvenile Diabetes Foundation Career Development Award and T. Morishima was supported by the Medical Research Council (Canada). This data was presented, in part, at the meeting of the American Diabetes Association in San Antonio, Texas, in June 1983.

\section{References}

1. Madison LL, Kaplan N (1958) The hepatic binding of $I^{131}$ labeled insulin in human subjects during a simple transhepatic circulation. J Lab Clin 52: 927-32

2. Field JB (1972) Insulin extraction by the liver. In: Grey RO, Astwood EB (eds) Endocrinology, Vol 1. Endocrine pancreas. American Physiology Society, Washington, p 505

3. Mondon CE, Olefsky JM, Doldas CB, Reaven GM (1975) Removal of insulin by perfused rat liver: effect of concentrations. Metab Clin Exp 51: 912-21

4. Rubenstein AH, Pottenger LA, Mako ME, Getz GS, Steiner DF (1972) The metabolism of proinsulin and insulin by the liver. J Clin Invest 51:912-21

5. Ooms HA, Arnould Y, Rosa U, Pennisi G, Franckson JRM (1968) Clearance metaboliques globales de l'insuline cristalline et d'insulines substituées au radioiode. Pathol Biol 16:241-245 
6. Sönksen PH, Tompkins CV, Srivastava MC, Nabarro JDN (1973) A comparative study on the metabolism of human insulin and porcine proinsulin in man. Clin Sci Mol Med 45: 633-654

7. Franckson JRM, Ooms HA (1973) The catabolism of insulin in the dog: evidence for the existence of two pathways. Postgrad Med J 49: $931-939$

8. Morishima T, Bradshaw C, Radziuk J (1985) Measurement using tracers of steady-state turnover and metabolic clearance of insulin in dogs. Am J Physiol 248 (Endocrinol Metab 11): E203-E208

9. Kaden M, Harding P, Field JB (1973) Effect of intraduodenal glucose administration on hepatic extraction of insulin in the anaesthetized dog. J Clin Invest 52: 2016-28

10. Harding PE, Bloom G, Field JB (1975) Effect of infusion of insulin into portal vein on hepatic extraction of insulin in anesthetized dogs. Am J Physiol 228: 1580-88

11. Jaspan J, Polonsky K (1982) Glucose ingestion in dogs alters the hepatic extraction of insulin: in vivo evidence for a relationship between biologic action and extraction of insulin. J Clin Invest 69 : $516-25$

12. Waldhausl W, Bratusch-Marrain $P$, Gasic S, Korn A, Nowotny $P$ (1982) Insulin production rate, hepatic insulin retention and splanchnic carbohydrate metabolism after oral glucose ingestion in hyperinsulinemia Type 2 (non-insulin-dependent) diabetes mellitus. Diabetologia 23: 6-15

13. Ishida T, Chap Z, Chou J, Lewis R, Hartly C, Entman M, Field JB (1983) Differential effects of oral, peripheral intravenous, and intraportal glucose on hepatic glucose uptake and insulin and glucose extraction in conscious dogs. J Clin Invest 72: 590-601

14. Polonsky K, Jaspan J, Emmanouel D, Holmes K, Moossa AR (1983) Differences in hepatic and renal extraction of insulin and glucagon in the dog; evidence of saturability of insulin metabolism. Acta Endocrinol 102: 420-427

15. Rubenstein AH, Clark JL, Melani F, Steiner DF (1969) Secretion of proinsulin C-peptide by pancreatic beta cells and its circulation in blood. Nature 224: 697-699

16. Stoll RW, Touber JL, Menahan LA, Williams RH (1970) Clearance of porcine insulin proinsulin and connecting peptide by the isolated rat liver. Proc Soc Exp Biol Med 133: 894-896

17. Kuhl C, Faber OK, Hornnes P, Jensen SL (1978) C-peptide metabolism and the liver. Diabetes 27 (Suppl 1): 197-200

18. Polonsky K, Jaspan JB, Pugh W, Cohen D, Schneider M, Schwartz T, Moossa AR, Tager H, Rubenstein AH (1983) Metabolism of C-peptide in the dog; in vivo demonstration of the absence of hepatic extraction. J Clin Invest 72:1114-23

19. Horwitz DL, Kuzuya H, Rubenstein AH (1976) Circulation serum C-peptide. A brief review of diagnostic implications. New Engl J Med 295: 207-209

20. Heding LG (1978) Insulin, C-peptide and proinsulin in nondiabetics and insulin treated diabetics. Characterization of the proinsulin in insulin-treated diabetics. Diabetes 27 (Suppl 1): 178-83

21. Polonsky KS, Rubenstein AH (1984) C-peptide as a measure of the secretion and hepatic extraction of insulin. Pitfalls and limitations. Diabetes 33: 486-494

22. Waldhausl W, Bratusch-Marrain P, Gasic S, Korn A, Nowotny P (1979) Insulin production rate following glucose ingestion estimated by splanchnic C-peptide output in normal man. Diabetologia $17: 221-227$

23. Faber OK, Hagen C, Binder C, Markussen J, Naithani VK, Blix PM, Kuzuya H, Horowitz DL, Rubenstein AH, Rossing N (1978) Kinetics of human connecting peptide in normal and diabetic subjects. J Clin Invest 62: 197-203

24. Eaton RP, Allen RC, Schade DS, Erickson KM, Standefer J (1980) Prehepatic insulin production in man; kinetic analysis using peripheral connecting peptide behaviour. J Clin Endocrinol Metab 51: $520-28$

25. Polonsky KS, Pugh W, Jaspan JB, Cohen DM, Harrison T, Tager HS, Rubenstein AH (1984) C-peptide and insulin and their secretion rates in the dog. J Clin Invest 74: 1821-1829
26. Bard Y (1974) Nonlinear parameter estimation. Academic Press, New York

27. Mendenhall W, Sincich T (1984) Statistics for the engineering and computer sciences. Dellen, San Francisco

28. Phillips DL (1962) A technique for the numerical solution of certain integral equations of the first kind. J Assoc Comput Mach 9: 97-101

29. Radziuk J (1977) The numerical solution from measurement data of liver integral equations of the first kind. Int $\mathbf{J}$ Num Meth Engin 11: 729-735

30. Horwitz DL, Starr JI, Mako MF, Blackard ME, Blackard WG, Rubenstein AH (1975) Proinsulin, insulin, C-peptide concentrations in human portal and peripheral blood. J Clin Invest 55: $1278-1283$

31. Kamazawa Y, Kuzuya T, Ide T (1968) Insulin output via the pancreatic vein and plasma insulin response to glucose in dogs. Am J Physiol 215: 620-626

32. Rappaport AM, Davidson JK, Kawamura T, Lin BJ, Zelin S, Henderson J, Haist RE (1968) Quantitative determination of insulin output following an intravenous glucose tolerance test in the dog. Can J Physiol Pharmacol 46: 373-381

33. Field JB (1972) Insulin extraction by the liver. In: Grey RO, Astwood EB (eds) Endocrinology, Vol 1. Endocrine pancreas, American Physiology Society, Washington, p 505

34. Ishiwata K, Hetenyi GJr, Vranic M (1969) Effect of D-glucose and of D-ribose on the turnover of glucose in pancreatectomized dogs maintained on a matched intraportal infusion of insulin. Diabetes 18: $820-827$

35. Bratusch-Marrain PR, Waldhausl WK, Gasic S, Hofer A (1984) Hepatic disposal of biosynthetic human insulin and porcine $\mathrm{C}$ peptide in humans. Metabolism 33:151-157

36. Goresky CA, Huet M, Villeneuve JP (1982) Blood-tissue exchange and blood flow in the liver. In: Zakim D, Boyer TD (eds) Hepatology. A textbook of liver disease. WB Saunders, Philadelphia, pp 32-63

37. Norwich RH, Pinto C, Morch JE, Zelin S (1974) A practical method for removing catheter distortions from indicator-dilution curves. Cardiovasc Res 8: 430-438

38. Rudenski AS, Matthews DR, Turner RC (1985) C-peptide kinetics assessed by a two pool model after somatostatin suppresion of endogenous secretion. Diab Res Clin Pract Suppl 1: 5481

39. Kuzuya T, Matsuda A (1976) Disappearance rate of endogenous human C-peptide from blood. Diabetologia 12: 519-521

40. Radziuk J, Morishima T (1986) Assessment of insulin kinetics in vivo. In: Clarke WL, Larner J and Pohl SL (eds) Methods in diabetes research, vol II. Clinical methods. John Wiley, New York, pp 91-106

41. Faber OK, Madsbad S, Kehlet H, Binder C (1979) Pancreatic beta cell secretion during oral and intravenous glucose administration. Acta Medica Scand Suppl 624: 61-64

42. Meistas MT, Rendell M, Margolis S, Kowarski AA (1982) Estimation of the secretion rate of insulin from the urinary excretion rate of C-peptide: study in obese and diabetic subjects. Diabetes 31: $449-453$

Received: 19 September 1985

and in revised form: 21 May 1986

\section{Dr. J. Radziuk}

Department of Medicine

Royal Victoria Hospital

687 Pine Avenue West, Rm. H7 783

Montreal, Quebec,

Canada H3A 1A1 